Eastern Illinois University

The Keep

Faculty Research and Creative Activity

Communication Studies

January 2012

\title{
Contesting Neoliberalism through Critical Pedagogy, Intersectional Reflexivity, and Personal Narrative: Queer Tales of Academia
}

Richard G. Jones

Eastern Illinois University, rgjones@eiu.edu

Bernadette Marie Calafell

University of Denver

Follow this and additional works at: http://thekeep.eiu.edu/commstudies_fac

Part of the Gender, Race, Sexuality, and Ethnicity in Communication Commons

\section{Recommended Citation}

Jones, Richard G. and Calafell, Bernadette Marie, "Contesting Neoliberalism through Critical Pedagogy, Intersectional Reflexivity, and Personal Narrative: Queer Tales of Academia" (2012). Faculty Research and Creative Activity. 4.

http://thekeep.eiu.edu/commstudies_fac/4

This Article is brought to you for free and open access by the Communication Studies at The Keep. It has been accepted for inclusion in Faculty Research and Creative Activity by an authorized administrator of The Keep. For more information, please contact tabruns@eiu.edu. 
Contesting Neoliberalism through Critical Pedagogy, Intersectional Reflexivity, and Personal

\author{
Narrative: Queer Tales of Academia \\ Richard G. Jones Jr. \\ Eastern Illinois University \\ Bernadette Marie Calafell \\ University of Denver
}

\begin{abstract}
In this essay, we use personal narrative to explore allies and alliance building between marginalized people working in and through higher education, with an eye toward interrogating the ways in which ideologies of neoliberalism work to maintain hierarchy through the legitimation of Othering. Inspired by Conquergood (1985), who calls scholars to engage in intimate conversation rather than distanced observation, we offer our embodied experiences as a way to use the personal to reflect upon the cultural, social and political. Our narratives often recount being out of place, moments of incongruence, or our marked Otherness. Through the sharing of these narratives, we will demonstrate the possibility for ally building based in affective connections forged through shared queer consciousness, paying particular attention to the ways in which neoliberal ideologies, such as individualism and postracism, may advance and impede such alliances.

Key Words: alliance building, feminist theory, intersectional reflexivity, neoliberalism, personal narrative, queer pedagogy

Jones, R. G., Jr., \& Calafell, B. M. (2012). Contesting neoliberalism through critical pedagogy, intersectional reflexivity, and personal narrative: Queer tales of academia. Journal of Homosexuality, 59(7), 957-981.
\end{abstract}


Contesting Neoliberalism through Critical Pedagogy, Intersectional Reflexivity, and Personal Narrative: Queer Tales of Academia

The 2010 midterm elections further confirmed the instantiation of neoliberal ideologies into "American values." On the evening of November 2, 2010, John Boehner, the Ohio Congressperson who ended up being the next Speaker of the House invoked the key tenets of neoliberalism when he stated the following in his victory speech: "We can celebrate when we have a government...that honors our Constitution and stands up for the values that have made America, America: economic freedom, individual liberty, and personal responsibility" (“Midterms 2010," 2010, n.p.). The anti-Washington, anti-incumbent political sentiment that prevailed in the 2010 midterm elections was imbued with neoliberal ideologies that, through the veil of the myth of meritocracy, support corporate economic interests at the expense of the most vulnerable in our society_marginalized and disenfranchised groups. As Kotz (2002) explains, neoliberal policy recommendations include "deregulation of business, privatization of public activities and assets, elimination of or cutbacks in social welfare programs, and reduction of taxes on businesses and the investing class" (p. 65). Writing before the "great recession" he continues, with eerie accuracy, to note that "the neoliberal model creates instability on the macroeconomic level...by loosening public regulation of the financial sector. This renders the system more vulnerable to major financial crises and depression" (p. 66). Even though these claims clearly make a case for neoliberalism's culpability in our current economic downturn, neoliberalism's suspicion of government intervention in economic regulation can be seen in current negative reactions to continued government spending to try to invigorate the economy. In short, Kotz argues that suspicion of government intervention is based on the "grounds that such intervention is likely to create more problems than it solves" (p. 64). In fact, neoliberal economic 
policies will likely not create more problems for big-business or the wealthy; however, the very voters who elected leaders, like Boehner, who taut these policies are not as likely to benefit. Slaughter and Rhoades (2004) explain: "The benefits of the neoliberal state [tend] to accrue less to the broad citizenry and more to large corporations, the wealthy, and the upper middle class" (pp. 309-310). These policies once again disenfranchise queers of color, and others, who are not represented within this upper middle class status.

Neoliberal politics have also created a backlash against higher education as we face the growing problem of state budget crises and higher education and public employees in general, rather large corporations, are scapegoated. Undoubtedly, neoliberal ideologies will shape the response to these economic crises, and in turn (re)shape higher education more generally. Scholars have already begun to critique neoliberalism's ideologies of curricular standardization, top-down management, proscriptions on behavior, and invasive systems of accountability (Giroux, 2010; Hammersley-Fletcher \& Qualter, 2009). We believe that this exigent moment provides a fertile opportunity to explore possible avenues of resistance regarding the constraining ideologies of neoliberalism, particularly as neoliberalism affects higher education.

Our personal narratives explore how neoliberalism operates in academia and how we as queer educators seek to connect across our difference through our shared experiences of Otherness. As we chart our shifting positionalities in the academy, we understand the importance of locating our experience within larger social, cultural, political, and economic climates from which they emerge (Berry \& Warren, 2009). We attempt to make transparent the opacity that sometimes shrouds the diffuse and disciplining power of the academy as an institution and reflect on how critical/queer pedagogy offers us tactics for countering institutional strategies imbued with neoliberalism, such as discourses that position students as consumers, reframe higher 
education as job training, and promote "civility" and accountability in ways that inhibit the academic freedom of cultural Others.

\section{$* * *$}

I remember our first meeting. It was years ago at the National Communication Association Convention. You were in North Carolina then, where I had just left to move to Syracuse. Both of us were in transition. The panel on Latino masculinities drew a scant crowd if I remember correctly, but there you were definitely engaged. Just a few months out of graduate school, suddenly in a tenure track position, I was still trying to find my place-What kinds of privileges come with the title Assistant Professor rather than doctoral candidate? I was in the midst of continual challenges based on my race, class, gender, and sexuality by faculty and students alike-How do you deal with the blatant homophobia and "fear" from students and educate faculty and staff who don't know how to respond? (Calafell, 2010a). How do you deal with the tokenizing of both you and your research? I was also in the midst of trying to work through the many layers of Homeland Security to sponsor my Egyptian partner (Calafell, 2008). In the midst of feeling out of place, both as a new professor and a Chicana in the academy, I used heterosexual privilege to sponsor him to stay in the United States. I am a critical scholar and was aware of all of these contradictions, but after 9/11 things became a lot less clear cut. But I digress...I return to you. A chance meeting, an email later, and then finally in 2006 we met again. I came to a new department and yours was one of the first faces I saw. I longed for spaces of connection, and I found them in a seminar in Performance Ethnography with graduate students who also aligned themselves with Other positionalities. Together we went on to Critical Sexuality Studies, a seminar where I continued to long for connection. In the end, I found connection as we worked as advisor and advisee on a dissertation project that blended 
intersectionality and queerness, a project that truly united our commitments. In the course of it all we became friends. How many times have we sat together talking about the ways we continue to be reminded of our Otherness in the academy? How many times have we commiserated over stories of love gone wrong? Our professional and personal lines continue to fluctuate.

After getting divorced I'm coming out all over again. I'm not being insensitive, I'm being honest. I'm not only single, but I'm queer. This was one of the first things that connected us. As someone who is bisexual I tread a fine line, always being aware of the ways I can and do sometimes draw on heterosexual privilege. Like Warren, I understand the tensions surrounding my identities, particularly around my bisexual queerness (Gust \& Warren, 2008).

You've heard this before, I do not want children. Uttering these words aloud always seems to elicit some heteronormative backlash, particularly in a department where I am the only queer faculty member and babies are suddenly around. I understand Dow's (2008) sentiments when she questions the ways heteronormativity fuels discourses about being family friendly in departments, but I also care about my colleagues and their children. I long for connection. I long for other queer bodies.

That was my first NCA, in Chicago in 2004, and it was quite a high for me. Not yet knowing either of us would end up at the same university, that chance meeting was a highlight of my conference. You're right, there weren't many audience members at the panel, but it was my first time hearing other academics discuss queerness, masculinity, and culture in critical, intersecting ways. Being a critical scholar, and a queer one at that, is isolating in most contexts, and I think we are quick to make affective ties when we're able to connect at conferences, via email, or even through the texts that our peers publish. I've been lucky to have a lineage of three 
female mentors, two of whom are women of color, that have prepared me to defend my scholarship, be proud of my blended academic and personal identities, and stand up for what I believe in when my voice is marginalized. I've always found it interesting that some of the key mentors in your academic journey were queer white men. It seems as though we were set-up to form an alliance even before that chance meeting at NCA.

As a graduate student, I learned from you and my other mentors to understand the politics of "playing the game" as well as the politics of resistance. We're not naïve enough to think that we'll get hired, retained, published, tenured, or promoted because we call people out for their privilege (regardless of their standing in the field and whether or not it's in a crowded public forum like a conference panel) or question and queer the academy. We also have to make concessions and placations. Just as you acknowledged the inherent contradictions between your critical/queer political commitments and your conscious enactment of heterosexual and citizenship privilege, I've learned to better negotiate the tensions between my queer and privileged (white, male) identities.

Through our alliance over the years, our positions have changed and we have earned higher credentials. Now that you're tenured, you have additional freedoms and additional responsibilities. Now that I'm in a tenure-track position, I'm learning even more about playing the game and when to stick my neck out or keep my head down. I think we help each other to remain reflexive as we share our challenges and rewards. We both have a certain amount of privilege to retreat to ostensibly safer places by "passing” for the purposes of access or advancement, yet we find ways to use our access to subvert the status quo, advocate for marginalized voices, and call out privilege. 
I'm sure our alliance threatens neoliberal ideals that seek to constrain the agency and voices of students and faculty within the confines of standardization, hierarchy, and corporatization. Our often-voiced dissatisfaction with uncritical diversity initiatives and multicultural programming that lack intersectionality has led to much change on the campus we previously shared. We continue to try to make change in the field through our scholarship, and daily challenge the traditional power dynamics of the classroom through critical communication pedagogy. My reflections on the power of alliance are not meant to be self-congratulatory. Alliance in the face of normative discourses ranging from color-blindness, to the myth of meritocracy, to neoliberalism is difficult, fraught, tenuous, and at times painful. But, our commitments to the performance paradigm, auto-methods, and narrative have been powerful outlets for these emotions, which we seek to embrace and learn from rather than ignore or disown through a guise of objectivity. And it's in this space of possibility between text (this narrative), performer (us), and audience (you, the reader) that our voices (ours and yours) come together.

We reflect on our relationship in order to frame and contextualize our discussion of the intersections of culture, identity, critical pedagogy, and narrative. We also understand the importance of recognizing the ways our identities and our bodies are situated within the academic world and the vulnerabilities that come with forging alliances across difference. As Johnson and Bhatt (2003) note, we are "lodged between the either and the or" in a society that marks some of our identities as superior and some as subordinate, and each of us must negotiate our dual existence (p. 230). As critical scholars, we center discussions of power in our scholarship and teaching, and we are careful to acknowledge our positionalities, but not list them 
as some sort of disclaimer. We identify as queer not just as a marker of sexuality but also of politics. Further, we draw on Gamson's (2000, p. 349) conceptualization of queer as a perspective that opposes established social and academic norms, critiques assimilationist and binary views of sexualities and identities, and questions identity politics. Although we focus on our identities in our narratives, we adopt performative (Conquergood, 1991; Langellier, 1999) and queer notions of identity (Gamson, 2000; Gamson \& Moon, 2004; Green, 2007; Khayatt, 2002) as fluid and constructed, maintained, and changed through narrative. Our queer approach is distinct from gay and lesbian studies, which may view identity as fixed, stable, or inherent within the individual (Yep, Lovaas, \& Elia, 2003). In fact, our queer-informed critique of neoliberalism is predicated on a rejection of individualism. We are also committed to queer scholarship that challenges the hegemony of whiteness that goes unquestioned in some queer studies (Johnson, 2006; Moreman, 2009; Ross, 2005).

As this paper unfolds we discuss connections between queer consciousness, intersectional reflexivity, and alliance building, but it is important to note that these connections emerge from our lived experiences with queer theory and critical pedagogy. We do not mean to conflate critical and queer pedagogy, as each has its scholarly lineage. However, we capitalize on the decentering philosophies and the emancipatory promises of each, and it is through these lenses that we examine neoliberalism. Further, we intersect these approaches and queer pedagogy by working together a politics of love, respect, and reciprocity that works against hierarchy (Calafell 2007) and ask what queer theory and queer identities might teach us about how our experiences and histories shape our pedagogy (Warren, 2011).

\section{Personal Narrative and Intersectional Reflexivity}


Personal narrative engages the politics of voice. Through our co-constructed personal narratives, we co-perform spaces of possibility where our queer identities and critical politics can talk back to hegemonic, heteronormative, and homonormative discourses (Corey, 1998; 2006). Additionally, our narratives affectively provide spaces for connection and understanding across difference. Even though our positionalities differ, our shared experiences of queerness, coupled with an affect of Otherness in academia offer a bridge to alliance. We use our narratives to demonstrate the complex and careful negotiations between identities and alliance building. While identity politics have come under critique as essentialist or outdated, we use this opportunity to demonstrate that identities do still matter. Scholars such as Yep (2003) have called for a move to explore queer diasporas. While this work is not about queer diaspora, we operate in the spirit of using queerness as a point of connection across differences while honoring our intersectional identities. Scholars such as Pérez and Goltz (2010) have explored the possibility of queer alliances across difference; however, we put this work in conversation with discourses of neoliberalism and critical communication pedagogy.

The power of personal narrative has been thoroughly explored in performance studies, and has also been theorized as an important part of identity and agency in critical pedagogy. Drawing on these two fields of study, we seek to use our personal narratives to counter the master narratives that shape and proscribe our experiences and performances within the academy (Corey, 1998). Additionally, we acknowledge that our narratives, and those of our students, can be read against totalizing narratives in order to resist and transform them (McLaren, 1995). The political possibilities further lie when those from different positionalities might be able to bodily experience or understand an Other identity. We complicate this moment further through intersectional reflexivity. 
As practitioners of critical communication pedagogy, we embrace the call for selfreflexivity (Fassett \& Warren, 2007). As scholars of culture, we are also committed to scholarship that explores intersections of identities. Although we acknowledge that, ideally, intersectionality would be reflexive and vice versa, we also know that these terms are conceptualized and employed in many different ways. Jones (2010) notes that "engaging in intersectional reflexivity requires one to acknowledge one's intersecting identities, both marginalized and privileged, and then employ self-reflexivity, which moves one beyond selfreflection to the often uncomfortable level of self-implication" (p. 122). Additionally, intersectional reflexivity should inform the research process and be present in the final scholarly product. Our narratives, through intersectional reflexivity, acknowledge our privileges and disadvantages as well as the power of our positions in academia. As educators we have the power to plant subversive, potentially transformative seeds of thought in the minds of our students, but we also have the privilege to retreat to the banking model of education, where we are more likely to be lauded than questioned. In working toward intersectional reflexivity we resist potential interpellation by discourses of neoliberalism that have infected the academy, including those that may tokenize or scrutinize us. As Nast and Pulido (2000) warn, our commitment to oppositional multiculturalism upsets the desire for universities to preserve consumer and corporate interests and socially nonconflictual climates and will likely cast us as trangressives and incite classroom-institutional harassment. Although our alliance is strengthened by the resolve of our resistance, through intersectional reflexivity we hold our bodies accountable to the ways we might also be complicit in neoliberal ideologies.

In writing the personal we further consider the ways our intersectionalities or positionalities may be used to advocate for our students and ourselves. Alcoff (2003), Calafell 
(2008; 2010a), Hu-DeHart (2000) have given testimony to the ways in which issues of race, class, gender, and sexuality permeate the academy. We follow a methodological vein forged by scholars such as Alexander (1999), Calafell (2010a/b), Patton (2004), and Taylor (2000), who have each used their own experiences to offer complex critiques of the academy by unpacking moments of rupture, in which they have been forced to examine how we are implicated and situated within what Hill Collins (2000) terms the matrix of domination. Further, we engage in self-reflexivity, as a tool through which those of us marked as Other can begin to intervene in our own complicity of the perpetuation of the status quo by unpacking the politics inherent in our lived experience — in our narratives. Our self-reflexivity also opens up a space for dialogue with one another as we engage in a form of Conquergood's (1985) dialogic performance that calls us to not only hear the Other's perspective, but also be accountable to it. Martinez (2003) challenges scholars to exercise self-reflexivity because our daily lives affect how we approach our research, teaching, and service whether we are conscious of it or not. Even consummate critical pedagogy scholars have been critiqued for not practicing the self-reflexivity about which they write. Fassett and Warren (2007) note, regarding McLaren's (1997) rejection of whiteness and avowal of a brown identity, that "being a critical scholar...is not about escaping your implication or complicity in systems of power, but, rather, about living there in that uncomfortable space" (p. 88).

\section{Neoliberalism, Higher Education, and Culture}

Liberalism, rooted in the philosophies of the Enlightenment, has worked to reinscribe the "virtues" of "individuality, autonomy, and moral self-development," (Parekh, 2005, p. 81) which are still present within neoliberalism and affect our institutions of learning and society in general. Neoliberal ideology is inherently contradictory, as it "is both egalitarian and inegalitarian, it 
stresses both the unity of mankind [sic] and the hierarchy of cultures, it is both tolerant and intolerant, peaceful and violent, pragmatic and dogmatic, skeptical and self-righteous" (p. 82). We see some of these contradictions play out in the following ways: neoliberalism's collusion with late-capitalism creates an ostensible level playing field, but only for those with the monetary capital to enter the game; countries and people are brought closer through technology and trade, but the digital divide and neo-colonialism reinforce the longstanding hegemony of the West; and, finally, from all these practices results the epistemic and physical violence inherent in a system that privileges some and oppresses Others. The violent potential of neoliberalism is also noted by Bourdieu (as cited in McLaren, 2003, p. 156), who makes the bold claim that the "gospel" of neoliberalism will not hesitate to destruct any obstacle in its quest for maximization of profit. As such, the quest for profit has infiltrated higher education, as the move toward privatization makes higher education resemble a corporate/competitive model ${ }^{\mathrm{i}}$. Neoliberal ideologies in higher education mirror the neoliberal policies of privatization and commercialization that have swept around the world. Although, universities were not key in creating neoliberal policies and ideologies, they have directly and indirectly endorsed such policies (Slaughter \& Rhoades, 2003, p. 20). ${ }^{\text {ii }}$

Neoliberal ideologies also infiltrate higher education's diversity initiatives through a turn toward corporate multiculturalism that "prepare[s] students to become workers culturally adept in laboring or exploiting others' labor in a global economy" (Nast \& Pulido, 2000, p. 725). Further, by adopting corporate multiculturalism, which frames diversity as entertaining and unproblematic, faculty who bring up issues of difference that "cause student-consumers discomfort" or who "oppose a profitseeking ethos" may "find themselves without institutional support, facing a hostile student [and administrative] population" (pp. 722-723). McLaren (as 
cited in hooks, 1994), derides "conservative and liberal [models] of multiculturalism...because when we try to make culture an undisputed space of harmony and agreement...we forget that all knowledge is forged in histories that are played out in the field of social antagonisms" (p. 31). Rather than critical historicization, called for above by McLaren, the view of multiculturalism that prevails on many campuses is more about numbers than inclusion (Williams, Berger, \& McClendon, 2005).

Neoliberalism's privileging of individualism and personal responsibility also influences notions of culture and identity. These discourses manifest in political rhetoric and policies that call for dismantling social welfare programs (Kotz, 2002) and reducing other "entitlements" such as health care, and social security (Slaughter \& Rhoades, 2004, p. 309). When identity is seen as fixed, stable, and emanating from within an individual, it is much easier to "blame" that person for their "problems." As is often the problem with discussions of race, the individual is put in the spotlight while systemic and institutionalized oppressive practices remain uncritiqued. For example, following the 2008 election, neoliberalism manifested prominently through the lens of postracism (Ono, 2010). This "disguised" racism can manifest in the classroom through students who deny the existence of racism, citing as "proof" that an African American man has been elected president. Ignoring the complexity of the situation or larger social/cultural contexts, their discourses deny racism, "overlaying it with an upbeat discourse about how things were never really that bad, are not so bad now, and are only getting better" (Ono, 2010, p. 227).

In addition to infiltrating diversity initiatives, neoliberal ideologies explicitly interfere with critical pedagogy in that they infiltrate and effect policy related to teacher education programs. ${ }^{\text {iii }}$ One aspect of critical teacher education that has come under suspicion is social justice oriented curricula (Sleeter, 2008). Spurring such suspicion is a general resistance to 
discussing systemic issues of oppression. In regards to postracism, Ono (2010) argues that denial of racism manifests itself in several forms including minimization, which casts racism as no longer important. This can further lead to charges of "reverse racism," which is "said to be perpetuated primarily by people of color" (p. 229). This strategy allows individuals to perform "strategic racial moves that help to avoid and ignore racism's past and present effects, including their very own performances” (p. 229, see also Nakayama \& Krizek, 1995; Warren, 2001).

Undergirding postracism discourses are clear connections to class, which are built upon neoliberalism's privileging of individualism and autonomy vis-à-vis the myth of meritocracy. Noting the intersections of race and class, hooks (1994) states that some people believe "that conditions of social equality are solidly in place [and] would enable any black person who works hard to achieve economic self-sufficiency" (p. 29). Again, the focus on individuals allows us to internally attribute a person's failures or successes and ignore external factors. If one buys into the myth of meritocracy, then the underlying assumption is that people who do not succeed are either not industrious or indolent. In the classroom, students can and do embody neoliberal voices such as postracism or charges of reverse racism. When we, as critical educators, question these assumptions, we invite the charge from students, administrators, colleagues, etc., that we are politicizing what should be a neutral space. Although we know the classroom is not a neutral space (Fassett \& Warren, 2007; hooks, 1994) we must still deal with the practicalities of the effects of such resistance on our pedagogical goals.

For some time I had been looking forward to teaching a graduate seminar on women of color feminist writers. It was a dream class; a class that centered the experiences of women of color feminists, not simply including them as supplemental in a larger discussion of feminist 
theory (i.e., mainstream white feminism). Initially I worried about whether the class would make. Would the majority white graduate student body at my university be interested in the voices of women of color? I also worried that the class would be appropriated by students who saw this as opportunity to engage in "training” strategies for dealing with Others. I was happily surprised when the class not only filled, but had students asking to be added despite enrollment limits. The class drew students from across disciplines. What I wasn't prepared for the constant fight to center whiteness by some of the white women in the class and the desire to center heterosexuality by some of the straight identified women in the class. While the class did have a few women of color, the majority of students enrolled were white women, save one biracial man. The struggle to center women of color's voices, not only in the texts that we read, but also in allowing the few women of color in the class to speak, was exhausting. Furthermore, I was continually cognizant of not allowing other students to try to make the women of color speak as "experts" of their communities. The class was quite literally a labor of love.

Reflecting on the experience I can see the ways neoliberal or postracist attitudes shaped some of what happened in the classroom. This manifested in the continual struggle by some students to re-center whiteness, a lack of reflexivity about standpoints, and an undercurrent of heteronormativity that I and the few queer students had to continually challenge. Even when many of texts were written by queer women who centered their queerness, often students would re-center it toward heteronormativity by discussing their own straight relational histories. My outing of myself as queer had little effect on getting some students to move past their heteronormativity. But nothing shook me more than the resistance I faced from one student in particular, Jenny. I had met Jenny the summer before the class started when she came to my office to discuss the possibility of taking classes in my department. Jenny, was a white, straight, 
second year graduate student in Education, with a specific focus on "multicultural" curriculum and instruction. Jenny shared her dissatisfaction with her current program for the lack of critical offerings; thus, she hoped our department could augment this. After mapping a possible course of study in our program Jenny decided she would start by taking my seminar.

Given the amount of time Jenny had staked in investing in the department, I had assumed she would be an active participant in the seminar. This however, this was not the case. Throughout the quarter she had sat quietly and smugly with an ambivalent and bored look on her face. She never spoke unless she had to. A very charitable reading of her behavior could be that she wanted to give Others space to talk or that she did not feel that she had the authority to speak. All I knew about her was that she was interested in multicultural education and that her husband was "Hispanic." Whenever she used this term I cringed, especially since we had read several authors that deconstructed the term, pointing to its offensiveness. It was not my intention to rob her of the ability to use the term, but in a critical classroom environment where it had been deconstructed, and was clearly offensive to me, a Latina professor, I expected a bit more sensitivity.

As the quarter progressed an essay written by a Jewish woman raised by lesbian parents resonated with Jenny, and suddenly for the first time she spoke more than a few sentences. I was extremely pleased and hoped that this was a sign that she was finally connecting with the material. The next class a student was facilitating discussion, and the readings for the day focused on perspectives of Arab and Arab American feminists. Part of the student's facilitation included a fishbowl exercise in which four students would sit in the center of the circle and discuss the readings while the rest of the class listened. When it was time for Jenny to sit in the fishbowl she was partnered with a Moroccan woman, and two white women. As the Moroccan 
student, Marina, began speaking about her reactions to the readings, the other white women in the group started engaging her. In the midst of her talking, Jenny shifted the conversation so that it was no longer about Marina's reaction to the readings, but instead became about her own experience as a white multicultural educator and the challenges she faced. I sat horrified, Marina looked frustrated, and some of the other students showed embarrassment about the shift in the course of the discussion. Once the fishbowl was over and the facilitator asked if we had comments, I took the opportunity to highlight the way whiteness was re-centered in the conversation. I assumed Jenny, as a "good" multicultural educator would be amenable to my comments and see this as a learning experience. This was far from the case. As I shared my comments, Jenny began to cut me off explaining that she was not "doing that." Jenny illustrated "the danger of thinking you got it" (Warren, 2010). Then she began to cry. As a woman of color and critical educator/researcher I am no stranger to this tactic. In fact I have written about it before (Calafell, 2010b) and experienced this many times over in my life as a graduate student, untenured faculty member, and now tenured faculty. This strategy is often used by white women in the classroom and in other professional settings against antiracist women of color, as it deflects blame and guilt, instead "victimizing" the white woman while centering whiteness and reaffirming the savage Otherness of women of color. It also often functions as an opportunity for white women to reinforce the bonds of their privilege with white men through the role of innocent victim who must be protected from Otherness. Historically, as we have seen white womanhood must be protected at all costs (Hill Collins, 2000). This manifestation of postracism elides histories and casts those who are marginalized as the aggressors or racists.

As the class ended, Jenny whimpered out of the room. Little did I know this would be the last I would see of her. I went home bothered by the experience, wondering if I had been too 
hard, wondering if I expected too much from graduate students... Had I expected too much from Jenny? Had I assumed she would be open to constructive criticism because she claimed to be committed to issues of difference? Was our understanding of difference and antiracist pedagogy that different? These questions flooded my mind throughout the night. The next day, when I logged onto Blackboard, I discovered that Jenny had dropped the class. Eight weeks of a tenweek quarter were easily dismissed with the click of a drop button. I heard from a few other students that Jenny had emailed them trying to rally them against me. All of this from a white woman educator who described herself as committed to "antiracist pedagogy. " I was angered and embarrassed. The questions I asked myself earlier remained. Had I expected too much? Was I too naïve? This was the first class I taught after being tenured; however, my level of vulnerability pre-tenure remained. What does tenure mean when you are a queer Chicana feminist educator? What are the privileges tenure affords you in this situation? How does the privilege of tenure factor in when you sit in a classroom where everyday is a struggle not to center whiteness and heteronormativity? What does it mean when daily you must put your queer and brown body on the line, often suffering substantial pain in the process?

Furthermore, I began to wonder if the class and Jenny's larger program of "multicultural curriculum” was more about cultural cache in the contemporary climate. Was there also an economic desire that drove her entry into and eventual "mastery" of the subject? Did she believe that because she was married to a "Hispanic" man and academically invested in these discourses that she was above critique? Did she desire multiculturalism on her own terms, and when they were challenged, cast me as the problem? I became individualized as the problem, not a larger system of power. My frustration with the situation increased when I would later find out that Jenny continued to pursue a professional relationship with a white woman 
colleague who also did work in culture. Elsewhere I have written with two of my former white women colleagues who actively practiced an understanding of intersectionality and coalitional politics, about the ways white women in academia are often positioned in departments as "good" versus their "bad" women of color colleagues (Faulkner, Calafell, and Grimes, 2009). It was happening again.

\section{Ostensible Inclusion Masks Neoliberal Othering}

Through neoliberal discourses, certain bodies become privileged while others become pathologized (Calafell, 2007; 2010a), and the hierarchy of identities that is created is validated, as neoliberalism facilitates some people's movement through spaces and hinders those who are marked as Other. In the above narrative, we can see how ideologies of individualism - and the privileges and discourses of blame that come with it — cast Jenny as the victim and the "Other" as aggressor. However, the framework of neoliberalism and late-capitalism paradoxically creates discursive spaces for anyone with enough monetary capital to purchase and cultivate "unique identities." These differentiated identities (Giddens, 1991) are commodified in that they are created around and by product consumption. In this sense, gay cultural identity, complete with the niche marketing and commodities that come with it, becomes more visible and ostensibly "included" in society. However, cultural critics question the legitimacy of such inclusion. Hill Collins (2004) questions this strategy in regards to representations of African Americans to argue that visibility in the media is often uncritically equated with gained power, and new packaging of quasi-feminist ideologies are often just as oppressive, if not more so than patriarchal ideologies. Additionally, Sender (2006) makes a similar claim about the Bravo cable network's Queer Eye for the Straight Guy, which has been likened to a form of gay minstrelsy in a format laden with 
consumerism, product placement, and corporate sponsorship. We are particularly troubled by the conflation of consumerism and citizenship in neoliberalism, which may lead society at large to celebrate consumer inclusion as a civil/human rights victory.

This type of superficial commercial inclusion is sometimes mirrored in the academy in that difference and diversity are lauded and sometimes resourced at curricular and extracurricular levels. As Hu-DeHart (2000) argues, universities may desire Other bodies, but do little to change academic cultures, as Others are instead expected to assimilate. Others, are included or tolerated to the extent that they remain docile, unthreatening, and invested in self-commodification rather than queer or "in-your-face." Those who defy expectations of middle class whiteness civility and heteronormativity are often disciplined for their failure or desire to perform within the hegemonic order (Calafell, 2008; 2010a, 2010b; hooks, 1994). We question the motives and outcomes of such inclusion in higher education.

Aside from being told, "Having a gay friend is cool!" by a popular cheerleader in high school who had only recently started talking to me, I'd never really thought of my gay identity as commodified. In fact, I, like many others, thought it was pretty revolutionary when Ellen came out on her show when I was in high school, and when Will and Grace became a big hit. It wasn't until graduate school, when a more critical consciousness germinated, that I began to question certain parts of my identity.

There is some irony in the fact that the institutions that exposed me to critical and queer theory are so resistant to incorporating them. As one of my queer, Chicano, dissertation participants put it when discussing his exposure to Chicana/o studies, "The white University taught me how to be brown." It is also in the context of academia that I've learned to use my 
queerness as capital, while being cognizant of the limited and conditional discursive space I was granted. However, I have an additional degree of passing privilege in that I can choose, in some situations, how high to wave my queer flag, if I choose to display it at all. Although queerness permeates my identities, my performances are not always already marked as marginal because my white, male privileged identities can be overshadowing. It's within this dialectic between passing and resistance that I've brushed against and felt the pull of neoliberal ideologies.

As an ambitions academic, there have been many occasions on which I've decided to strategically use the unearned entitlements that come with my white, male privilege. I've never had problems attaining leadership roles on campus and in the community. People seem to want to listen to me. I've also learned that, in these situations, people read me as normative rather than queer. I actually had a former colleague who worked in multicultural student affairs tell me that she thought I was a graduate student in the business school and probably a Republican when she first met me. I began to wonder if I was playing the game a little too well. Was I becoming one of "those people" who gets some power, some recognition and wakes up one day a conservative? I questioned to what extent I felt accountable to intervene in the way people read me.

I was a key player in getting gender identity and gender expression added to the nondiscrimination policy at our university. No one really questioned my motives, or presumed I had an activist agenda. When we presented the case to the Board of Trustees, I don't think the social justice implications really mattered to them. What they found most persuasive on our executive summary was the comparison to our aspirational peers and the idea that including this language would put us in a group of progressive universities, bringing good publicity and more profits. I reflected on the ease with which I slipped into PR/marketing mode, and, honestly, how 
surprisingly comfortable I felt in that mode. Even though I was uncomfortable-as a person with a working class background from rural Appalachia-sitting in a literal mansion (where our Trustees met) and wearing a "white man power suit," I felt good about this instance of undercover queerness for the purposes of passing a policy important to me as a queer activist and trans-ally. But it's largely through the power vested in me through my privileges that I was able to access that space. What could I have done to queer that space more? How much queerness could that space tolerate? How much of myself am I willing to suppress in order to "play the game?" How am I complicit in perpetuating neoliberalism because I relied on arguments based on corporate competition?

We know that tactics of resistance can be co-opted and turned or subsumed into hegemonic strategies (DeCerteau, 1984). I see this happen regularly when people "think they got it" and begin to avow their work as critical. As a Basic Course Director, I incorporate critical pedagogy into the training of my graduate teaching assistants, and I've had to explain to them that not assigning a grade on a minute paper isn't critical pedagogy. I've explained to colleagues that doing research on lesbian mothers doesn't instantly make your research agenda critical or queer. I've reviewed numerous conference papers and journal submissions that poorly attempt auto-ethnography by using the personal voice without connecting to the theoretical or methodological genealogy that informs it. The academy will gladly open up a small and tolerated space for alternative discourses. However, it should never be forgotten that the space has been granted as a placation, in an attempt to legitimate, sanitize, surveil, and perhaps coopt.

\section{Neoliberalism and Critical Pedagogy}


The above personal narratives address the ways in which neoliberal ideologies affect our experiences within higher education. Our bodies are desired because they fulfill "diversity initiatives" and because our expertise in culture and communication can be spun as a recruiting tool attracting tuition dollars from domestic and international students, which in-turn can develop a "financially strong and internationalized alumni base" (Nast \& Pulido, 2000, p. 725).

Otherness is often seen as a means to further someone else's agenda; however, when we do not always react or perform appropriately we are disciplined (such as in the case of Jenny).

Additionally, we are aware of our abilities to act as shapeshifters or tricksters who play with and against the very tools that the academy tries to use against us, such as in the discussion of the presentation to the Board of Trustees or the ability to use one's white male identity to challenge systems of oppression. As Others we recognize the challenges and possibilities the we face in the academy.

While critical pedagogy seeks to unite teacher and student, we are aware that suspicion by colleagues, administrators, and other students regarding activist-oriented pedagogy, socialjustice oriented curriculum, and close mentoring relationships impedes transformational ally building (Calafell, 2007). Moments that rupture this layer of suspicion prove to be powerful moments of teaching and learning. Freire (1970/2003) stresses the fostering of solidarity between teacher and student through communication. However, we are careful to follow the heed of Torres (2003), who challenges Freire's notions, which do not always work, particularly in the context of historically marginalized faculty teaching privileged students. She writes, "Dealing with the sensitivities, hostilities, and defensiveness of privileged students cannot be my full time concern. It robs marginalized and oppressed students of my attention and takes valuable time away from their engagement in the learning process" (Torres, 2003, p. 91). 
Our locations on the borders of society and identity sometimes offer us an escape from surveillance. But, as we know, even though the economic policies of neoliberalism open borders for the purposes of trade (whether trafficking goods, services, or even human beings), the individualism and xenophobia that comes with neo-conservatism increases the border patrol. The borders we traverse are "historically constructed and socially organized within maps of rules and regulations that serve to either limit or enable particular identities, individual capacities, and social forms" (Giroux, 2005, p. 136). Sometimes a student, like Jenny, may act as a border patrol agent.

McLaren (1995) defines border identities as "narratives and counternarratives which we choose to enact...in the context of our everyday, mundane practical existence" (p. 106). While McLaren's conceptualization of narrative captures the potential for resistance inherent in personal narratives that we privilege in our scholarship, his discussion of border identities differs from ours, which is based on the work of queer feminists of color like Anzaldúa (1999). ${ }^{\text {iv }}$ In spite of this difference, we highlight McLaren's concept here because of its connection to affect and neoliberal consumerism: "Border identities are anchored in and are the outcome of those social practices that configure experience and shape affective investment in such experience in relation to narratives of liberation which challenge the market identities produced by the New Right's narratives of consumer citizenship" (McLaren, 1995, p. 106). As demonstrated in Calafell (2007), affective connections across difference, even constructed hierarchical differences are important, particularly in mentoring relationships between faculty and students of color. These affective connections offer spaces for possibility, transgression, and home-place in a university setting that does not welcome Otherness (Calafell 2007). 
She has been missing a lot of class ever since that day. It was the day we discussed Denzel Washington and Anthony Hopkins. She said that Washington winning the Oscar for playing a villain was just the same as Hopkins winning for Hannibal Lecter. This, after months of critical scholarship and months of her protests as she refused to acknowledge her privileges as a heterosexual white woman. I finally told her she had missed the point. After weeks of not coming to class she returned, emboldened. She started being obviously rude to me in class. The uncomfortable tension filled the room. Students seemed unsure of how to react. I asked her to step out in the hallway and the screaming match began.

"You've made me look like a white racist bitch!"

"You're not going to pull that on me...that's a common tactic used by white students to disempower women of color in the classroom. " Did I really say that? Yes, I did.

Across the hall, the department's "star faculty" peered out his door in amusement, but did nothing to help the situation. Only, when I talked to my teaching supervisor for the class, a queer white man, did someone get it. In fact, he was mortified. We sat in his office, and reveled in this moment of connection born out of our shared experiences of difference in the academy, and the classroom in particular. This was a place of safety with one of the first professors who taught me queer theory and about being queer in the academy.

\section{Alliances and Queer Consciousness}

Our conceptualization of queer consciousness is informed by the work of queer scholars of color who have critiqued the lack of inclusion and reflexivity in much of queer theory (Cohen, 2005; Johnson, 2003; Moreman, 2009; Ross, 2005). The exclusive focus on the hetero/homosexual binary of early queer theory left out people who are heterosexual but may 
also be "queer" in terms of how their multiple identities, aside from sexual orientation, impact their lived experience. Cohen (2005) instructively explains the failures of both identity politics and queer opposition to identity politics and, drawing on Hill Collins (2000), provides an alternative to single-identity-based politics by presenting a more intersectional view of queerness that accounts for multiple identities and how power and agency operate within those identities. Rather than focusing exclusively on heterosexism, Cohen (2005) calls for a broader theoretical framework based in social justice when she states "queer activists who evoke a single-oppression framework misrepresent the distribution of power within and outside of gay, lesbian, bisexual, and transgendered communities, and therefore limit the comprehensive and transformational character of queer politics" (p. 25). Cohen (2005) proposes a framework where identification is achieved in terms of relative power position rather than socio-cultural identity. Rather than organizing around the reductive and exclusive categories of heterosexual and homosexual, Cohen suggests coalitional activism. Similarly, Yep (2003) demonstrates the violence of heteronormativity on individuals of all sexual orientations, again moving toward the possibility of coalitional connections.

As a first generation college student, I didn't have much guidance in terms of preparing for college. However, my innate curiosity and often involuntary social isolation led me to reading and research as a hobby. Part of what spurred my growth as an organic intellectual was the drive to make sense out of the mess of identities inside me. In graduate school, I was exposed to queer theory. I was immediately attracted to its postmodern, and cerebral challenges to my ways of thinking. Through my readings, I began to see that some of the critiques I had of my own gay identity, and gay culture in general, were echoed in and validated by queer theory-critiques 
of political apathy, assimilationist rhetoric, and commercialization, for example. When I entered my doctoral program, I decided to explicitly change my identification from gay to queer. As a result, I experienced some negative backlash from community members, and some of my friends. Intellectually, the move was intriguing and satisfying. Emotionally, it was like a second coming out. I had gotten a little too comfortable, too complacent, as a gay man, and was now thrown back into a space of liminality and messiness-a space that I love because it's creative and dynamic... but a space that has also been uncomfortable and lonely. Writing has often been an outlet for the regular confusion and occasional realizations that resulted from my reading and research on issues of culture and identity. As I dug, excavated, and unpacked my memories, I discovered that I had a history of questioning the identities I was encouraged to uncritically consume - often with similarly negative results to my reidentification as queer. Now, I theorize that my ongoing experiences of incongruency were germinal seeds for the development of a queer consciousness-moments of incongruency such as: being the gay Southern Baptist who later renounced Christianity; being physically and verbally assaulted because I was the supposed-to-be-redneck who instead sat with and talked to Black kids on the bus and later identifies as an anti-racist; and being a gay man who resists assimilation. Although these embodied experiences of queerness pre-date my exposure to queer theory, I carry their significance in my flesh.

As Darder (2003) recounts, Freire also espoused such a view of coalitional activism in his commitment to alliance over identity politics. We find it productive to bring together conversations regarding queer theory, intersectionality, and critical pedagogy in order to highlight their important similarities. Our ongoing experiences of incongruency with various 
cultural and social identities and the consciousness-raising that resulted relates to Carrillo Rowe's (2008) scholarship on feminist alliances, which draws on and extends Segrest's work on “belonging.” Carrillo Rowe (2008, p. 27) describes a processual development of self and consciousness. While we share narratives of salient moments regarding our identities, we consciously avoid thinking of these narratives as linear and final, which is an academic convention of Western ways of thinking and writing (Minh-ha, 1989). Presenting linear narratives as finite and discrete signifiers of the meaning of our queer identities would go against conceptualizations of queer as unstable and fluctuating, and would be incongruent with the politics of the performance paradigm we outlined earlier.$$
* * *
$$

The first time I taught intercultural communication, I offered an optional final exam as a way for students who may have not done well on the other forms of assessment to improve their grade. On the day of the exam, three students showed up. Two of them were the only white men in the class. Throughout the semester, they had struggled with our discussions of racism, classism, and privilege. They saw this as an opportunity to resist what they probably assumed was my anti-white, anti-male agenda by verbally marking their presence in the room. "Of course it's the two white guys who are here today," they said. I thought, "I am a white man too, doesn't' that make three of us?" I wasn't hurt by their lack of identification with me, but it was a salient moment of being marked in the classroom as different from many of my white male students. Even though we would check the same demographic boxes for race and gender on a survey or form, we perform whiteness and maleness in different ways, and I often find it difficult to see white straight men as potential allies. But I must remember that my acknowledgement of 
my white privilege doesn't mean that those I may want to ally with who are marginalized because of their race won't have the same difficulties seeing me as a potential ally.

As a critical scholar committed to reflexivity, I have moments of difficulty reconciling the citationality of my body. For example, even as I work to subvert masculinity through my queerness, the materiality of my body carries with it the historical, political, social, and biological citationality of masculinity (and patriarchy), which may be perceived as hegemonic and/or threatening. The fact that I'm a feminist who has worked to educate other men about sexual assault doesn't prevent some women from crossing to the other side of the street at night as I near them on the walk from my office to my car. They don't know I also get a visceral sense of fear and cross the street when I see a few male undergraduates approaching me on the sidewalk at night. But I am aware that my male body signifies to them the very same male aggression and male sexual violence that has victimized me, so I acknowledge that their fear is valid and that my body will always carry this baggage no matter how much of a feminist and anti-violence advocate I am.

A question we are compelled to consider is, "What makes an ally?" An alliance cannot be formed by the privileged "transgressing" a societal boundary to interact with the marginalized. hooks (1994) recounts "interacting with liberal white folks who believed that having a black friend meant that they were not racist, who sincerely believed that they were doing us a favor by extending offers of friendly contact for which they felt they should be rewarded" (p. 25). Jones (2010) also argues that allying oneself with marginalized groups should not be a selfcongratulatory effort. To be an ally, one must not just be willing but feel compelled to face the daily epistemic and physical violence that threatens marginalized groups, Che Guevara stated, 
"Solidarity means running the same risks" (Johnson \& Bhatt, 2000, p. 230). But how can we move toward more alliance building for the sake of social justice in the face of neoliberalism?

Extending Alcoff's (1991-1992) reminder to critically question political accountability and positionality, Carrillo Rowe (2005) calls for a shift from 'I," which “announces 'I am...' to a sense of 'self' that is radically inclined toward others, toward the communities to which we belong, with whom we long to be, and to whom we feel accountable" (p. 18). This means critically minded people, scholars and citizens, must move beyond an individualized location, expanding their accountability from self, to others and self. Through our narratives, we have traced how the development of queer consciousness moved us toward alliance, which critiques the individualism that so heavily influences and colonizes the imaginary within neoliberalism. Our narratives also recount the pain and isolation that also comes with the daunting task of bridging difference.

We find hope in Freire's commitment to establishing critical networks of educators to remake culture and "[confront] the devastating impact of neoliberal economic and social policies" (Darder, 2003, p. 505). Jones (2010) likened such critical networks to a "rhizomatic underground railroad" through which we may transport our radical ideas as critical educators (p. 125). We also find inspiration in hooks (1994) reminder that our collective commitment to cultural diversity must not be squelched and take pause in her attention to the reality that "we must accept the protracted nature of our struggle and be willing to remain both patient and vigilant" (p. 33). Our alliances may not always be perfect, but as critical scholars we must find comfort in the messiness to be able to live with ourselves. Rather than measuring our success on the perfection of our performance as a critical scholar, "our solidarity must be affirmed by shared 
belief in a spirit of intellectual openness that celebrates diversity, welcomes dissent, and rejoices in collective dedication to truth" (p. 33).

While we are committed to the possibility of connections across difference we also acknowledge that privilege may also play a factor in the ability to forge coalitions. At times we wonder what gets lost or sacrificed in practice rather than theory. Is too early to speak across differences when many of us have yet to be heard and recognized, let alone see this in practice? In the past I have always understood the importance of coalition across race and ethnicity, but for the first time understood the practice of feminist coalitional politics when I worked side by side with two white women colleagues to challenge a pattern of racism, sexism, and homophobia that persisted in an academic setting. These women had not been as severely subjected to the experiences I had, yet they literally laid their bodies, reputations, careers, and experiences on the line with me. They worked to try to understand the affect of Otherness in the academy, and one queerly understood it. They exhibited the ethics of love that should underlie coalitional politics across difference. Additionally, in a recent reflection upon a continued collaboration with a feminist of color scholar, I continue to be amazed by the care, support, mentoring, and ethics practiced in the various ventures we have undertaken together. She continues to reaffirm for me the importance of friendships among women of color in academia and how these friendship can serve as a space to begin to start radical change in our academic environments. We must continue to work toward coalition, but always with intersectional reflexivity driving our moves, so that we may challenge ourselves even when we think we've got it. We cannot allow ourselves the arrogance of mastery.

\footnotetext{
${ }^{i}$ See White's (2000) edited volume, Campus, Inc.: Corporate Power in the Ivory Tower.
} 
ii Just a few examples of how higher education has been commercialized include: expansion of student loan programs that position students as consumers, passage of the Bayh-Dole law that allowed universities to own and profit from faculty research, discouraging unionization, enacting policies that allow for more adjunct faculty, and revising accreditation practices to approve forprofit colleges and universities (Slaughter \& Rhoades, 2004, pp. 20-22).

${ }^{\text {iii }}$ See Groenke and Hatch's (2009) edited volume, Critical Pedagogy and Teacher Education in the Neoliberal Era.

${ }^{\text {iv }}$ For a detailed discussion of the differing conceptualizations, by McLaren and Anzaldúa, of borders, see Elenes (2003). 


\section{References}

Alcoff, L. M. (1991-1992). The problem of speaking for others. Cultural Critique, 20, 5-32.

Alcoff, L. M. (2003). Introduction. In L. M. Alcoff (Ed.), Singing in the fire: Stories of women in philosophy (pp. 1-13). Lanham, MD: Rowman \& Littlefield.

Alexander, B. K. (1999). Performing culture in the classroom: An instructional (auto)ethnography. Text and Performance Quarterly, 19, 307-331. doi:

$10.1080 / 10462939909366272$

Anzaldúa, G. (1999). Borderlands—La Frontera: The new Meztiza. San Francisco, CA: Aunt Lute Books.

Berry, K. \& Warren, J. T. (2009). Cultural studies and the politics of representation: Experience <-> subjectivity <-> research. Cultural Studies $\Leftrightarrow$ Critical Methodologies, 5, 597-607. doi: $10.1177 / 1532708609337894$

Calafell, B. M. (2007). Mentoring and love: An open letter. Cultural Studies $<=>$ Critical Methodologies 7, 425-441. doi: 10.1177/1532708607305123

Calafell, B. M. (2008). Performing the responsible sponsor: Everything you never wanted to know about immigration post-9/11. In A. Valdivia (Ed.), Latina/o communication studies today (pp. 69-89). New York, NY: Peter Lang.

Calafell, B. M. (2010a). When will we all matter?: Exploring race, pedagogy, and sustained hope for the academy. In D. L. Fassett \& J. T. Warren (Eds.), The Sage handbook of communication and instruction (pp. 343-359). Thousand Oaks, CA: Sage.

Calafell, B. M. (2010b). Notes from an "angry woman of color": Academic policing and disciplining women of color in a post (fill in the blank) era. Journal of Communication Inquiry, 34, 240-245. doi: 10.1177/0196859910371375 
Carrillo Rowe, A. (2005). Be longing: Toward a feminist politics of relation. NWSA Journal, 17, 15-46.

Carrillo Rowe, A. (2008). Power lines: On the subject of feminist alliances. Durham, NC: Duke University Press.

Cohen, C. (2005). Punks, bulldaggers, and welfare queens: The radical potential of queer politics? In E. P. Johnson \& M.A. Henderson (Eds.), Black queer studies: A critical anthology (pp. 21-51). Durham, NC: Duke University Press.

Conquergood, D. (1985). Performing as a moral act: Ethical dimensions of the ethnography of performance. Literature in Performance, 5, 1-13.

Conquergood, D. (1991). Rethinking ethnography: Towards a critical cultural politics. Communication Monographs, 58, 179-194.

Corey, F. C. (1998). The personal against the master narrative. In S. Dailey (Ed.), The future of performance studies: Visions and revisions (pp. 249-253). Washington, DC: National Communication Association.

Corey, F. C. (2006). On possibility. Text and Performance Quarterly, 26, 330-332. doi: $10.1080 / 10462930600828758$

Darder, A. (2003). Teaching as an act of love: Reflections on Paulo Freire and his contributions to our lives and our work. In A. Darder, M. Baltodano, \& R. D. Torres (Eds.), The critical pedagogy reader (pp. 497-510). New York, NY: RoutledgeFalmer.

DeCerteau, M. (1984). The practice of everyday life. Berkeley, CA: University of California Press.

Dow, B. J. (2008). Does it take a department to raise a child? Women's Studies in Communication, 31, 158-165. 
Elenes, C. A. (2003). Reclaiming the Borderlands: Chicana/o identity, difference, and critical pedagogy. In A. Darder, M. Baltodano, \& R. D. Torres (Eds.), The critical pedagogy reader (pp. 191-210). New York, NY: RoutledgeFalmer.

Fassett, D. L. \& Warren, J. T. (2007). Critical communication pedagogy. Thousand Oaks, CA: Sage.

Faulkner, S., Calafell, B, M. \& Grimes, D. (2009). Hello Kitty goes to college: Poems about harassment in the academy. In M. Prendergrast, C. Leggo, \& P. Sameshima (Eds.), Poetic inquiry: Vibrant voices in the social sciences (pp. 187-208). Rotterdam: Sense Publishers.

Freire, P. (2003). Pedagogy of the oppressed: $30^{\text {th }}$ anniversary edition. New York, NY: Continuum. (Original work published 1970)

Gamson, J. (2000). Sexualities, queer theory, and qualitative research. In N. K. Denzin \& Y. S. Lincoln (Eds.), Handbook of qualitative research ( $2^{\text {nd }}$ ed.) (pp. 347-365). Thousand Oaks, CA: Sage.

Gamson, J., \& Moon, D. (2004). The sociology of sexualities: Queer and beyond. Annual Review of Sociology, 30, 47-64. doi: 10.1146/annurev.soc.30.012703.110522

Giddens, A. (1991). Modernity and self-identity: Self and society in the late modern age. Stanford, CA: Stanford University Press.

Giroux, H. (2005). Border crossings: Cultural workers and the politics of education ( $2^{\text {nd }}$ ed.). New York, NY: Routledge.

Giroux, H. (2010). Public values, higher education and the scourge of neoliberalism: Politics at the limits of the social. Culture Machine. Retrieved from http://www.culturemachine.net/index.php/cm/article/viewArticle/426 
Green, A. I. (2007). Queer theory and sociology: Locating the subject and the self in sexuality studies. Sociological Theory, 25, 26-45. doi: 10.1111/j.1467-9558.2007.00296.x

Groenke, S. L., \& Hatch, J. A. (Eds.). (2009). Critical pedagogy and teacher education in the neoliberal era: Small openings. New York, NY: Springer.

Gust, S. W. \& Warren, J. T. (2008). Naming our sexual and sexualized bodies in the classroom and the important stuff that comes after the colon. Qualitative Inquiry, 14, 114-138. doi: $10.1177 / 1077800407308819$

Hammersley-Fletcher, L., \& Qualter, A. (2009). From scholars to higher education: Neoliberal agendas and implications for autonomy. Journal of Educational Administration and History, 41, 363-375. doi: 10.1080/00220620903211570

Hill Collins, P. (2000). Black feminist thought: Knowledge, consciousness, and the politics of empowerment. (2nd ed.). New York, NY: Routledge.

Hill Collins, P. (2004). Black sexual politics: African Americans, gender, and the new racism. New York, NY: Routledge.

Hobson, K. (2009). "You gotta have faith" that "I'm your man": Exploring drag king performances through a queer relational lens." Unpublished manuscript, presented at the 2011 Western States Communication Association conference. Monterey, CA.

hooks, b. (1989). Talking back: Thinking feminist, thinking black. Boston, MA: South End Press.

hooks, b. (1994). Teaching to transgress: Educating as the practice of freedom. New York, NY: Routledge.

Hu-DeHart, E. (2000). Office politics and departmental culture. In M. García (Ed.), Succeeding in an academic career: A guide for faculty of color (pp. 27-38). Westport, 


\section{CT: Greenwood.}

Johnson, E. P. (2003). Appropriating Blackness: Performance and the politics of authenticity. Durham, NC: Duke University Press.

Johnson, E. P. (2006). “Quare” studies, or (almost) everything I know about queer studies I learned from my grandmother. In E. P. Johnson \& M. G. Henderson (Eds.), Black queer studies (pp. 124-157). Durham, NC: Duke University Press.

Johnson, J. R., \& Bhatt, A. J. (2003). Gendered and racialized identities and alliances in the classroom: Formations in/of resistive space. Communication Education, 52, 230-244. doi: $10.1080 / 0363452032000156217$

Jones, R. G., Jr. (2010). Putting privilege into practice through "intersectional reflexivity": Ruminations, interventions, and possibilities. Reflections: Narratives of Professional Helping, 16, 122-125.

Khayatt, D. (2002). Toward a queer identity. Sexualities, 5, 487-501. doi:

\section{$10.1177 / 1363460702005004006$}

Kotz, D. M. (2002). Globalization and neoliberalism. Rethinking Marxism, 14, 64-79. doi: $10.1080 / 089356902101242189$

Langellier, K. M. (1999). Personal narrative, performance, performativity: Two or three things I know for sure. Text and Performance Quarterly, 19, 125-144. doi: $10.1080 / 10462939909366255$

Martinez, J. M. (2003). Racisms, heterosexisms, and identities: A semiotic phenomenology of self-understanding. In G. A. Yep, K. E. Lovaas, \& J. P. Elia (Eds.), Queer theory and communication: From disciplining queers to queering the discipline(s) (pp. 109-128). Binghamton, NY: Harrington Park. 
McLaren, P. (1995). Critical pedagogy and predatory culture: Oppositional politics in a postmodern era. London, UK: Routledge.

McLaren, P. (1997). Decentering whiteness. Multicultural Education, 5, 4-11.

McLaren, P. (2003). Revolutionary pedagogy in post-revolutionary times: Rethinking the political economy of critical education. In A. Darder, M. Baltodano, \& R. D. Torres (Eds.), The critical pedagogy reader (pp. 151-184). New York, NY: RoutledgeFalmer.

“Midterms 2010: John Boehner's victory speech in full.” (2010, Nov. 3). Retrieved from http://www.telegraph.co.uk/news/worldnews/northamerica/usa/uspolitics/8106711/Midterms-2010-John-Boehners-victory-speech-in-full.html

Minh-ha, T. (1989). Woman, native, other: Writing postcoloniality and feminism. Bloomington, IN: Indiana University Press.

Moreman, S. T. (2009). Rethinking Dwight Conquergood: Toward an unstated cultural politics. Liminalities: A Journal of Performance Studies, 5(5), 1-13.

Munoz, J. E.. (2009). Cruising utopia: The then and there of queer futurity. New York, NY: New York University Press.

Nakayama, T. K., \& Krizek, R. L. (1995). Whiteness: A strategic rhetoric. Quarterly Journal of Speech, 81, 291-309.

Nast, H. J., \& Pulido, L. (2000). Resisting corporate multiculturalism: Mapping faculty initiatives and institutional-student harassment in the classroom. Professional Geographer, 52, 722-737. doi: 10.1111/0033-0124.00261

Ono, K. A. (2010). Postracism: A theory of the "post" - as political strategy. Journal of Communication Inquiry 34, 227-233. doi: 10.1177/0196859910371375

Parekh, B. (2005). Liberalism and colonialism: A critique of Locke and Mill. In J. N. Pieterse \& 
B. Parekh (Eds.), Decolonization of imagination: Culture, knowledge, and power (pp. 8198). London, UK: Zed Books.

Patton, T. O. (2004). Reflections of a Black woman professor: Racism and sexism in academia. Howard Journal of Communications, 15, 185-200. doi:

$10.1080 / 10646170490483629$

Pelias, R, J. (2005). Performative writing as scholarship: An apology, an argument, an anecdote. Cultural Studies $\Leftrightarrow$ Critical Methodologies, 5, 415-424. doi:

$10.1177 / 1532708605279694$

Pérez, K. \& Goltz, D. B. (2010). Treading across Lines in the Sand: Performing bodies in coalitional subjectivities. Text and Performance Quarterly, 30, 247-268. doi: $10.1080 / 10462937.2010 .481797$

Ross, M. B. (2005). Beyond the closet as raceless paradigm. In E. P. Johnson \& M.A. Henderson (Eds.), Black queer studies: A critical anthology (pp. 161-181). Durham, NC: Duke University Press.

Sender, C. (2006). Queens for a day: Queer Eye for the Straight Guy and the neoliberal project. Critical Studies in Media Communication, 23, 131-151. doi: $10.1080 / 07393180600714505$

Slaughter, S., \& Rhoades, G. (2004). Academic capitalism and the new economy: Markets, state, and higher education. Baltimore, MD: The John Hopkins University Press.

Sleeter, C. (2008). Equity, democracy, and neoliberal assaults on teacher education. Teaching and Teacher Education, 24, 1947-1957. doi: 10.1016/j.tate.2008.04.003

Taylor, J. (2000). On being an exemplary lesbian: My life as a role model. Text and Performance Quarterly, 20, 58-73. doi: 10.1080/10462930009366283 
Torres, E. E. (2003). Chicana without apologies: The new Chicana cultural studies. New York, NY: Routledge.

Warren, J. T. (2001). Doing whiteness: On the performative dimensions of race in the classroom. Communication Education, 50, 91-108. doi: 10.1080/03634520109379237

Warren, J. T. (2010). It really isn't about you: Whiteness and the dangers of thinking you got it. In T. K. Nakayama \& R. T. Halualani (Eds.), The handbook of critical intercultural communication (pp. 446-460). Malden, MA: Wiley-Blackwell.

Warren, J. T. (2011). Reflexive teaching: Toward critical autoethnographic practices of/in/on pedagogy. Cultural Studies $\Leftrightarrow$ Critical Methodologies, 11 (2), 139-144. doi: $10.1177 / 1532708611401322$

White, G. D., \& Hauck, F. C. (Eds.). (2000). Campus, Inc.: Corporate power in the ivory tower. Amherst, NY: Prometheus Books.

Williams, D. A., Berger, J. B., \& McClendon, S. A. (2005). Toward a model of inclusive excellence and change in postsecondary institutions. Retrieved from Association of American Colleges and Universities website: http://www.aacu.org/inclusive_excellence/documents/Williams_et_al.pdf

Yep, G. A. (2003). The violence of heteronormativity in communication studies: Notes on injury, healing, and queer-world-making. Journal of Homosexuality, 45, 11-59. doi: $10.1300 / J 082$ v45n02_02

Yep, G. A., Lovaas, K. E., \& Elia, J. P. (2003). Introduction: Queering communication: Starting the conversation. In G. A. Yep, K. E. Lovaas, \& J. P. Elia (Eds.), Queer theory and communication: From disciplining queer to queering the discipline(s) (pp. 1-10). Binghamton, NY: Harrington Park Press. 